


\title{
Conceptual problems of investigation and prevention of enforced disappearance of persons in the conditions of armed aggression
}

\author{
DOI: https://doi.org/10.46398/cuestpol.3969.03
}

\author{
Mirkovets Dmytro * \\ Atamanchuk Volodymyr ** \\ Marko Sergii *** \\ Dubivka Irina $* * *$ \\ Matsola Antonina *****
}

\section{Abstract}

The article highlights the results of a study of the situation with official investigations into criminal offenses related to the enforced disappearance of persons in the context of armed aggression in eastern and southern Ukraine. The example of individual criminal proceedings presents some systemic problems that arise during the investigation of the facts of disappearance and suggests possible ways to solve them. There are several «blocks» of problems that lie in the field of criminal law, criminology, and criminal procedure. The points of view of scientists and practitioners on this problem are highlighted. It is concluded that Ukraine, in today's conditions, needs to take measures aimed at improving the legal mechanisms of observance and protection of the right of persons staying in its territory to freedom from enforced disappearance, as well as intensifying law enforcement agencies to prompt, complete and impartial investigation of such facts, their proper qualification, search for victims, identification of those responsible for their disappearance,

* Candidate of Science in law, Deputy Chiefs of the Main Investigation Department, State Bureau of Investigation, Kyiv, Ukraine, ORCID ID: https://orcid.org/oooo-0003-2539-2824. Email: a55555555@ukr.net

** Candidate of Science in law, Associate Professor, Department of Forensic Support and Examination of Educational and Scientific Institute № 2, National Academy of Internal Affairs, Kyiv, Ukraine, ORCID ID: https://orcid.org/oooo-0oo2-1464-7871. Email: atamanchykvlad@ukr.net

*** Candidate of Science in law, Associate Professor of the Department of Criminal Procedure and Criminology of the Faculty № 1 of the Institute for Training Specialists for National Police, Lviv State University of Internal Affairs, Lviv, Ukraine, ORCID ID: https://orcid.org/oooo-0002-9778-0570. Email: marko.sergii@gmail.com

**** Candidate of Science in law, Senior investigator in especially important cases of the 1 st department of the pre-trial investigation department of the National Police of Ukraine, Kyiv, Ukraine, ORCID ID: https://orcid.org/oooo-0oo2-7189-3630. Email: irinadubivka@ukr.net

***** Candidate of Science in law, Associate Professor of the Department of Criminal Law and Procedure, State higher educational institution «Uzhhorod National University», Uzhhorod, Ukraine, ORCID ID: https://orcid.org/oooo-0002-8678-7697. Email: ma0507@ukr.net 
ensuring that victims receive timely and adequate compensation. The methodological basis for writing the article was a dialectical-materialist method, as well as the set of general scientific and special methods and techniques of scientific knowledge.

Keywords: enforced disappearance; criminal liability; criminal proceedings; qualification; investigation.

\section{Problemas conceptuales de investigación y prevención de la desaparición forzada de personas en condiciones de agresión armada}

\section{Resumen}

El artículo destaca los resultados de un estudio de situación con investigaciones oficiales sobre crímenes relacionados con la desaparición forzada de personas en el contexto de agresión armada en el este y sur de Ucrania. El ejemplo de algunos procesos penales presenta algunos problemas sistémicos que surgen durante la investigación de desapariciones y sugiere posibles formas de solucionarlos. Hay varios «bloques» de problemas en el campo del derecho penal, la criminología y el procedimiento penal. Se destacan las opiniones de científicos y profesionales sobre este problema. Se concluye que, en las condiciones actuales, Ucrania debe tomar medidas destinadas a mejorar los mecanismos legales de observancia y protección del derecho de las personas que permanecen en su territorio a no desaparecer, así como activar las instituciones responsables de hacer cumplir la ley para investigar de manera imparcial tales hechos, calificación adecuada, búsqueda de víctimas, identificación de los responsables de su desaparición, asegurando una reparación oportuna y adecuada a las víctimas. La base metodológica para la redacción del artículo fue un método dialéctico-materialista, así como el conjunto de métodos y técnicas científicos generales y especiales del conocimiento científico.

Palabras clave: desaparición forzada; responsabilidad penal; proceso penal; calificación; investigación.

\section{Introduction}

The Constitution of Ukraine provides for the protection of the rights and freedoms of every citizen and declares that a person, his life, health, honor and dignity, inviolability, and security are determined by the highest social 
Mirkovets Dmytro, Atamanchuk Volodymyr, Marko Sergï, Dubivka Irina y Matsola Antonina Conceptual problems of investigation and prevention of enforced disappearance of persons in the conditions of armed aggression

value (Article 3) (Constitution of Ukraine, 1996). The success of this activity largely depends on the theoretical development of combating certain types of crime and the effective activities of law enforcement agencies in the fight against serious and especially serious crimes of selfish violence. Real enforcement of these rights is guaranteed by the rules of criminal law, which establish liability for encroachment on the liberty and inviolability of the person. These are, in particular, the criminal remedies provided for in Article $146^{1}$ of the Criminal Code of Ukraine «Forced Disappearance» (Criminal Code of Ukraine, 2001). The act of enforced disappearance is one of the most brutal human rights violations, the absolute nature of which is enshrined in the International Convention of 2006 (Tsviki, 2017).

Enforced disappearances have become a global problem that is not limited to any region of the world. Being in the past mostly a product of military dictatorial regimes (Forced or involuntary disappearance of persons, 2019), now enforced disappearances can occur in difficult conditions of local and interstate-armed conflicts. After the transition of the armed conflict in the east to the south of Ukraine to the phase of low intensity, the number of disappearances decreased, but they remain widespread (Forced disappearances in Ukraine and disappearances during the military conflict in the east in 2014-2018).

The lack of a unified methodology for determining missing persons, as well as the lack of coordination between different government agencies, have led to different data on the number of disappearances in a zone of military conflict - from several hundred to several thousand people. States parties to the relevant treaties, in addition to the measures they provide for the prevention of enforced disappearances, are obliged to include such acts as criminal offenses in national law (Yeroshkin, 2019), to take all possible and necessary measures aimed at immediate and effective investigation of each case of the disappearance of a person, to establish the culprits, to ensure observance and restoration of the rights of victims of such facts and their relatives.

Criminal offenses, liability for which is provided by Art. 1461 of the Criminal Code of Ukraine, referred to the jurisdiction of the pre-trial investigation of the National Police of Ukraine, the proceedings are not carried out as for crimes committed during hostilities. At the same time, on September 3, 2015, a separate specialized Office for the Investigation of Crimes against the Peace and Security of Mankind and International Offenses was established within the Chief Military Prosecutor's Office of the Prosecutor General's Office of Ukraine. On the fact of military aggression on the territory of Ukraine. We can state that currently there are a number of conceptual problems of investigating and preventing enforced disappearances in the context of armed aggression in eastern and southern Ukraine, which necessitates a comprehensive scientific study 
and development of scientifically sound proposals to improve existing legislation and practice. Application.

\section{Methodology of the study}

The methodological basis for writing the article was a dialecticalmaterialist method of scientific knowledge of socio-legal phenomena, as well as the set of general scientific and special methods and techniques of scientific knowledge that are currently used in legal literature, which made it possible to study raised problems in the unity of their social content and legal form. In particular, the authors used the following methods to achieve this goal and to provide science-based conclusions. One of the main methods for writing this scientific work was of analysis and synthesis, which allowed identifying the main criminal procedural and criminological problems of the enforced disappearance of persons in the context of armed conflict in some territories of Ukraine, to develop proposals and recommendations of organizational, tactical and legislative nature. Based on the synthesis, are formulated conclusions and proposals on the research topic.

The logical-semantic method made it possible to form, deepen and concretize the categorical apparatus of research, in particular, to establish the relationship between the concepts of «enforced disappearance», «imprisonment», «representative of the state» and «representatives of a foreign state» and more. The system-structural method used to identify typical shortcomings of qualifications, to conduct certain procedural actions in the investigation of crimes under Art. $149^{1}$ of the Criminal Code of Ukraine. To study the problems of investigation and prevention of enforced disappearances, legal support for the effectiveness of such activities, a comparative legal method was used, which analyzed the current criminal, criminal procedure legislation.

\section{Analysis of recent research}

The works of such scientists as Andrushko A.V. (2019), Voitovich E.M. (2019), Guzeeva O.S. (2014), Kabanets L.V. (2019), Mazurok O.Ya. (2015), Shulga O.V. (2016), Chornous Yu.M. (2013), and others are devoted to the study of the issues under consideration. Without diminishing the role of these scientists, there are still many problematic issues related to the investigation and prevention of crimes under Art. $146^{1}$ of the Criminal Code of Ukraine. Currently, there are significant gaps in the implementation of appropriate qualifications, rapid, complete, and effective investigation of enforced disappearances in Ukraine, which highlights the need to improve the methodology of investigation of these crimes, to develop an effective mechanism for their prevention. 
The purpose of the article is a comprehensive theoretical and applied study of certain criminal procedural and criminological problems of the enforced disappearance of persons in an armed conflict in Ukraine, development of proposals and recommendations of organizational, tactical, and legislative nature aimed at improving the investigation and prevention of crimes under Art. $146^{1}$ of the Criminal Code of Ukraine.

\section{Results and discussion}

One of the main tasks of every modern democratic and civil state is the protection and defense of human rights (Bondaruk et al., 2021). The Constitution of Ukraine in Section II enshrined a fairly broad, diverse in content list of natural and inalienable human, and civil rights. These include, in particular, the right of every person to respect for his or her dignity (Part 1, Article 28) and the right to liberty and security of person (Part 1, Article 29). In turn, the provisions of Section III of the Special Part of the Criminal Code of Ukraine are aimed at protecting these rights. In particular, Art. $146^{1}$ of the Criminal Code of Ukraine defines criminal liability for enforced disappearance (Criminal Code of Ukraine, 2001). Enforced disappearances violate the full range of human rights enshrined in the Universal Declaration of Human Rights and enshrined in the International Covenants on Human Rights, as well as in other major international human rights instruments, such as the right to recognition of legal personality; the right to liberty and security of person; the right not to be subjected to torture and other cruel, inhuman or degrading treatment or punishment; the right to life when a missing person is killed; the right to individuality; the right to a fair trial and judicial guarantees; the right to an effective remedy, including redress and compensation; the right to know the truth about the circumstances of the disappearance. Besides, the disappearance of people usually entails violations of various economic, social, and cultural rights, negatively affecting their realization by the victim's family members.

The disappearance of the main breadwinner, especially in less affluent communities, often puts the family at a standstill, in which many of the rights enshrined in the International Covenant on Economic, Social and Cultural Rights, in particular the right to protection of the family and providing her with assistance; the right to an adequate standard of living; the right to health; right to education (Forced or involuntary disappearance of persons, 2019).

Under conditions of physical and psychological restriction in the exercise of their rights, a person detained in a place not established by the investigation is vulnerable. Vulnerability is a condition in which a person is deprived or restricted in his/her ability to resist violent or other unlawful 
acts due to physical or mental characteristics or other circumstances caused by the relevant characteristics (Matvieieva et al., 2021).

Ukrainian and international human rights organizations have repeatedly referred to the facts of enforced disappearances in the context of armed conflict in their reports. In particular, the Center for Civil Liberties in a joint report with the International Federation for Human Rights (FIDH) (Eastern Ukraine. Civilians caught in the crossfire) noted that violations of the rights of civilians in eastern Ukraine have signs of both crimes against humanity and, in some cases, military crimes. This means, among other things, that the investigative units of the National Police of Ukraine, the Security Service of Ukraine, and the Prosecutor General's Office of Ukraine have to deal with a category of crimes with which they have not encountered these events. The situation is complicated by legal contradictions caused by the lack of consistent assessment of the events in Donbas as an armed conflict and consistent recognition of all legal consequences of this fact (Odegov, Hrytsenko and Shcherbachenko, 2018).

We consider it expedient to single out in the article several «blocks» of problems that lie in the plane of criminal law, criminology, and criminal procedure. At one time, formulating the objective side of enforced disappearance in both parts of Article $146^{1}$ of the Criminal Code of Ukraine, the legislator proceeded from the provisions of Art. Art. 2 and 6 of the Convention for the Protection of Human Rights and Fundamental Freedoms. However, compared with international norms, Art. $146^{1}$ of the Criminal Code of Ukraine did not provide for instructions on the construction of «leaving a person without the protection of the law» as a consequence of committing illegal acts; complicity in this act; circumstances that may mitigate (aggravate the return of the missing person alive, clarify the circumstances of the enforced disappearance or identify the perpetrators of the act of enforced disappearance) or aggravate (the death of the missing person, the act of enforced disappearance of pregnant women, minors, the disabled or others) persons) criminal liability (Enforced Disappearance: Problematic Issues of Criminal Liability).

Lawyers pay attention to other shortcomings. In particular, this norm contains only typical forms of imprisonment (arrest, detention, abduction), so their list is not exhaustive, and therefore the legal construction of «deprivation of liberty in any other form» means that similar illegal actions may be committed that will preclude a person from exercising his or her true will (for example, unreasonable pretext or detention). It emphasizes the lack of logic in the formulation of sanctions, disproportions in the definition of «representative of the state» and «representatives of a foreign state» in the note to Art. $146^{1}$ of the Criminal Code of Ukraine, etc. (Enforced Disappearance: Problematic Issues of Criminal Liability). 
Mirkovets Dmytro, Atamanchuk Volodymyr, Marko Sergï, Dubivka Irina y Matsola Antonina Conceptual problems of investigation and prevention of enforced disappearance of persons in the conditions of armed aggression

We pay attention to other problems as well. In particular, when describing enforced disappearances in the context of armed conflict and occupation, law enforcement officers often do not take into account the provisions of Art. 438 of the Criminal Code of Ukraine, which established stricter liability for violations of the laws and customs of war, and, in contrast to Art. $146^{1}$ of the Criminal Code of Ukraine has no statute of limitations. Also, current Ukrainian law allows for amnesty for those involved in enforced disappearances. This state of affairs, paradoxically, facilitates the prospects of kidnappers of Ukrainian citizens, especially if such kidnappers are the same officials. Thus, Ukraine does not guarantee the inevitability of punishment for enforced disappearances if the relevant representative of the Russian occupation administration appears before a Ukrainian court in the controlled territory (Report on the human rights situation in the temporarily occupied Autonomous Republic of Crimea and the city of Sevastopol, Ukraine, 2018).The above indicates the need for serious regulatory improvement of Art. $146^{1}$ of the Criminal Code of Ukraine, which will undoubtedly contribute to the improvement of law enforcement practice in criminal proceedings for the forcible destruction of a person.

We consider it expedient to review organizational and practical problems that prevent the search for victims of enforced disappearances. First, it should be emphasized that the law enforcement agencies of the Russian Federation ignore the facts of the investigation of these criminal offenses committed in the occupied territories of Ukraine, and the initiated criminal proceedings are closed. Such passivity in these matters, the unwillingness to conduct a thorough investigation is apparently due to the involvement of FSB officers, members of the so-called Donbas self-defense, «Crimean self-defense» and other organizations loyal to the Russian occupation administration, to enforced disappearances in Crimea. Temporarily occupied the Autonomous Republic of Crimea and the city of Sevastopol (Ukraine, 2018). At the same time, Ukraine is limited in international legal means to bring Russia to justice for enforced disappearances in the occupied territories. In particular, Ukraine is deprived of the opportunity to use the mechanisms provided by the International Convention for the Protection of All Persons from Enforced Disappearance, including the right to sue the International Court of Justice, as Russia is not a party to this convention. of Crimea and the city of Sevastopol (Ukraine, 2018).

In our opinion, the effectiveness of the search for missing persons in the temporarily occupied territories of Ukraine and bringing the perpetrators to justice will be facilitated by a set of organizational, tactical, and legislative measures, in particular:

- synchronization of the sanctions list by Ukraine, the USA, and the countries of the European Union, which should include law 
enforcement officers and organizations controlled by the Russian Federation that are involved in enforced disappearances in the occupied Crimea and obstruct thorough investigation (Enforced disappearances: problems of search and responsibility, 2020).

- developing a unified approach to the classification of crimes related to the violation of the enforced disappearance of a person.

- strengthening responsibility for enforced disappearances.

- search for missing persons following international standards.

- competent application by the plaintiffs of the case-law of the European Court of Human Rights.

- close coordination between relatives of missing persons, Ukrainian law enforcement agencies, human rights organizations and the UN Working Group on Enforced and Involuntary Disappearances. Special attention should be paid to the study of the conceptual provisions of the modern criminal process, as well as the peculiarities of their practical implementation in terms of solving the problem highlighted in the article. Determining territorial jurisdiction for pretrial investigation of criminal offenses committed in the occupied territory by pre-trial investigation bodies located at a considerable distance from the crime scene (residence of most witnesses and victims) and having difficult transport accessibility (bad car and / combination). This situation creates unjustified difficulties in the investigation, as the investigator is not able to personally carry out most procedural, including investigative (search) actions. When determining territorial jurisdiction, preference should be given to those pre-trial investigation bodies that are located in the administrative centers of the respective regions and the settlements closest to them (Odegov et al., 2018, p. 28).

It should be noted that as part of the administrative-territorial reform, the criminal bloc and pre-trial investigation bodies of the National Police in the territories where overload was recorded were strengthened (Ihor Klymenko presented a new model of organizing the activities of the National Police of Ukraine, 2021). Also, the Order of the Prosecutor General's Office № 54 of 02.03.2021 «On certain issues of ensuring the start of specialized prosecutor's offices in the military and defense sphere (district rights) » approved a list of specialized prosecutor's offices in the military and defense sphere (district rights) of the beginning of work of specialized prosecutors' offices in the military and defense sphere (on the rights of the district), 2021). It seems that such organizational innovations should have a positive impact on the provision of effective prosecutorial oversight, as well as on the level of professional training of law enforcement officers involved in the investigation of enforced disappearances. 
Mirkovets Dmytro, Atamanchuk Volodymyr, Marko Sergï, Dubivka Irina y Matsola Antonina Conceptual problems of investigation and prevention of enforced disappearance of persons in the conditions of armed aggression

Another problem in the investigation of enforced disappearances, which partly follows from the previous one, is the lack of promptness in the actions of law enforcement officers (prompt response to appeals of relatives of missing persons; lack of timely and formulated investigative versions in criminal proceedings); formal nature without taking into account the specifics of the criminal offense). Unjustified delays in conducting certain procedural, including investigative (search) actions, primarily with the appointment and conduct of examinations. Delays in recognizing the relatives of the missing victims and their interrogation in this status were revealed in the criminal proceedings № 12015230000000136 dated 06.04.2015 on the fact of the missing disappearance of E. Apselyamov (Criminal proceeding № 12015230000000136, 2015). At the same time, the materials of the pre-trial investigation do not contain information that would justify such delays in the appointment and conduct of examinations.

It is necessary to pay attention to the frequent absence in the materials of criminal proceedings of data on the state and results of the search for victims in the established ORS «Search». See, for example, criminal proceedings № 42015010000000124 of 04.09.2015, initiated on the fact of illegal imprisonment of $\mathrm{M}$. Arislanov (Criminal proceedings № 42015010000000124, 2015). The investigator's instructions to the officers of the operational unit to conduct investigative (search) actions are sometimes formal and meaningless. Employees of the relevant operational unit also formally treated them. These shortcomings are characteristic of the criminal proceedings № 42014000000000468 dated 04.06.2014, initiated on the facts of missing disappearance and illegal imprisonment of activists of the public organization «Ukrainian House» T.D. Shaimardanova, S.S. Zinedinova and L.A. Korzha (Criminal proceedings № 42014000000000468, 2014).

A common problem for almost all criminal proceedings of the studied category is insufficient diligence during investigative (search) actions. In many criminal proceedings initiated on the grounds of missing persons, investigative (search) actions did not have a clearly defined purpose (were not aimed at verifying a certain investigative version), were superficial and inconsistent. Scholars and practitioners also draw attention to the insufficient use in the investigation of these criminal offenses of opportunities and modern achievements of forensic techniques, forensic methods (means and techniques) of fixing the appearance of criminals (in particular, verbal presentation of the appearance of criminals in procedural documents) (protocols of interrogation of victims, as a rule, do not contain the detailed description of the appearance of criminals); photo composite portrait/photo work). It is indicated to ignore the possibility of identification of victims (criminals) and objects by photographs, video materials (video files), reference / forensic records, etc. (Odegov et al., 2018, p.). 
It is also necessary to state the lack of proper departmental control and prosecutorial supervision in the form of procedural guidance of pretrial investigation in criminal proceedings on the facts of the enforced disappearance of persons. Unfortunately, the lack of information about the state and progress of the pre-trial investigation also often characterizes such criminal proceedings. In the case of enforced disappearances, victims do not fully enjoy the right granted to them to review the materials of the pre-trial investigation.

Among other things, this is since during the transfer of materials to another body of pre-trial investigation, victims were often not informed about the new place of investigation. Such a shortcoming was revealed in the criminal proceeding № 12020010000000124 of 18.08.2020, initiated on the fact of disappearance in the area of the anti-terrorist operation in the Donetsk region Shugaeva O.L. (Criminal proceeding № 12020010000000124, 2020).

The analysis of the outlined problems in the field of application of the provisions of the criminal procedure law encourages the development of appropriate response measures, in particular, to strengthen departmental control and prosecutorial oversight of compliance with the law during pretrial investigation in criminal proceedings on enforced disappearances. First of all, it is about: the need to provide investigators with the reasonable frequency of reasonable instructions to conduct specific investigative (investigative) and other procedural actions within the time limits clearly defined by law and/or the prosecutor, the head of the pre-trial investigation body, to ensure proper implementation of the relevant instructions; if necessary, initiate before the heads of the pre-trial investigation body the issue of removal of the investigator from the pre-trial investigation and appointment of another investigator in case of ineffective investigation of the disappearance of persons with signs of violence.

As for research institutions of the Ministry of Internal Affairs of Ukraine, it, together with the Prosecutor General's Office of Ukraine, should develop and bring to the attention of subordinate investigative units' certain forensic methods of investigating enforced disappearances. When developing appropriate methods should take into account international experience in documenting criminal offenses under Art. $146^{1}$ of the Criminal Code of Ukraine and other crimes committed on the border and temporarily occupied territory of Ukraine. We should not ignore the recommendations of other scholars to increase the effectiveness of law enforcement in the fight against crimes related to an unlawful deprivation of liberty or kidnapping: improving methods of collecting intelligence to identify organized structures involved in crimes against personal liberty, nature their activities, relations between them (including transnational); research into the methods they use for self-defense; creation of specialized units in law enforcement agencies 
that would allow «entry» into criminal organizations (Kabanets, 2019, p. 34 ). It should be noted that these proposals are general, intersectoral in nature.

\section{Conclusions}

In general, it should be summarized that Ukraine, like other countries in a situation of armed conflict caused by the occupation of their territories, needs to take measures to improve the legal mechanisms of observance and protection of the right of persons on its territory to freedom from violence. Disappearance, as well as the intensification of law enforcement agencies to prompt, complete and impartial investigation of such facts, their proper qualification, search for victims, identification of those responsible for their disappearance, ensuring that victims receive timely and adequate compensation.

It is necessary to improve the regulations of Art. 146-1 of the Criminal Code of Ukraine, which, no doubt, promotes the improvement of law enforcement practice in criminal proceedings for the forcible destruction of a person. The effectiveness of the search for missing persons in the temporarily occupied territories of Ukraine and bringing the perpetrators to justice will be facilitated by a set of organizational, tactical, and legislative measures, in particular: synchronization of the legislative list by Ukraine, the United States and the European Union; search for missing persons following international standards; developing a unified approach to the classification of crimes related to the violation of the enforced disappearance of a person; strengthening responsibility for enforced disappearances; competent application by the plaintiffs of the case-law of the European Court of Human Rights; close coordination between relatives of missing persons, Ukrainian law enforcement agencies, human rights organizations and the UN Working Group on Enforced and Involuntary Disappearances.

\section{Bibliographic References}

CONSTITUTION OF UKRAINE: LAW OF UKRAINE. June 28, 1996, No. 254k/96-VR. Available online. In: https://zakon.rada.gov.ua/laws/ show/254К/96-вр. Consultation date: 28/03/2021.

CRIMINAL CODE OF UKRAINE: LAW OF UKRAINE. 2001. No. 2341-III. Available online. In: https://zakon.rada.gov.ua/laws/show/2341-14. Consultation date: 28/03/2021 (In Ukrainian).

ANDRUSHKO, Andrij. 2019. "Regarding criminal liability for enforced 
disappearance" In: Transcarpathian legal readings: materials of the XI International scientific-practical conference (Uzhhorod, April 11-31), pp. 202-209.

BONDARUK, Mukola; MELENKO, Sergiy; OMELCHUK, Liubov; RADCHENKO, Liliya; LEVENETS, Anzhela. 2021. "Juvenile Justitia and the protection of children's rights in European Court of Human Rights" In: CUESTIONES POLÍTICAS. Vol. 39 No. 68, p. 172.

CHORNOUS, Yulia. 2013. Forensic support of pre-trial investigation in cases of crimes of the international character: dissertation of Dr. Jurid. Science. National academy of internal affairs. Kyiv 2013. 310 p.

CRIMINAL PROCEEDING № 12015230000000136 from 06.04.2015. 2015. on the fact of the disappearance of Apselyamov E. Part 1 of Art. 115 of the Criminal Code of Ukraine. Acquaintance with the case in the Investigative Department.

CRIMINAL PROCEEDING № 12020010000000124 from 18.08.2020. 2020. On the fact of disappearance Shugaeva O., part 1 of Art. 115 of the Criminal Code of Ukraine. Acquaintance with the case in the Investigative Department.

CRIMINAL PROCEEDING № 42014000000000468 dated 04.06.2014. 2014. on the fact of missing disappearance and illegal imprisonment of activists of the public organization «Ukrainian House» Shaimardanov T., Zinedinov S. and Korzh L. item 2 h. 2 Art. 115, part 1 of Art. 115, part 1 of Art. 146 of the Criminal Code of Ukraine. Acquaintance with the case in the Investigative Department.

CRIMINAL PROCEEDING № 42015010000000124 dated 04.09.2015. 2015. on the fact of illegal imprisonment of Arislanov M. Part 1 of Art. 146 of the Criminal Code of Ukraine. Acquaintance with the case in the Investigative Department.

DECISION OF THE INVESTIGATING JUDGE OF THE DZERZHINSKY DISTRICT COURT OF KHARKIV. 2020. Case No. 638/15890/19. Proceedings № 1-x/638/188/20. Available online. In: https://rrg.gp.gov. ua/reestr-kriminalnih-provadzhen. Consultation date: 28/03/2021. (In Ukrainian)

EASTERN UKRAINE CIVILIANS CAUGHT IN THE CROSSFIRE. 2015. Available online. In: https://www.fidh.org/IMG/pdf/eastern_ukraineld.pdf. Consultation date: 28/03/2021.

ENFORCED DISAPPEARANCE: PROBLEMATIC ISSUES OF CRIMINAL LIABILITY. 2020. Available online. In: https://sud.ua/ru/ 
Mirkovets Dmytro, Atamanchuk Volodymyr, Marko Sergii, Dubivka Irina y Matsola Antonina Conceptual problems of investigation and prevention of enforced disappearance of persons in the conditions of armed aggression

news/blog/173139-nasilnitske-zniknennya-problemni-pitannyakriminalnoyi-vidpovidalnosti. Consultation date: 28/03/2021.

ENFORCED DISAPPEARANCES: PROBLEMS OF SEARCH AND RESPONSIBILITY. Crimea SOS: Internet article. April 27, 2020. Available online. In: https://krymsos.com/news/nasilnitskizniknennya-problemi-poshuku-ta-vidpovidalnosti. Consultation date: 28/03/2021. (In Ukrainian).

IHOR KLYMENKO PRESENTED A NEW MODEL OF ORGANIZING THE ACTIVITIES OF THE NATIONAL POLICE OF UKRAINE. 2021. In: Government Portal. Available online. In: https://www.kmu.gov.ua/ news/igor-klimenko-prezentuvav-novu-model-organizaciyi-diyalnostinacionalnoyi-policiyi-ukrayini. Consultation date: 28/03/2021. (In Ukrainian).

KABANETS, Lyudmila. 2019. Means of prevention of illegal imprisonment or kidnapping: international experience: dissertation of the candidate of legal sciences University State Fiscal Service of Ukraine, Irpin. 235 p.

MATVIEIEVA, Liliia; BALTADZHY, Polina; SHMALENKO, Iuliia; YEFTIENI, Natalia; IVANCHENKO, Olga. 2021. "Legal protection of vulnerable groups of population: practice of the European Court of Human Rights" In: CUESTIONES POLÍTICAS Vol. 39, No. 68, p. 138.

MAZUROK, Oleg. 2015. "Forensic support of investigation of crimes related to the disappearance of a person" In: Current issues of improving legislation and law enforcement: materials of the International scientific-practical conference (Zaporizhzhya, October 23-24, 2015), pp. 128-131.

ODEGOV, Oleksandr; HRYTSENKO, Natalia; SHCHERBACHENKO, Volodymyr. 2018. Crimes without punishment: human rights violations during the armed conflict in eastern Ukraine, Kyiv, 64 p.

REPORT ON THE HUMAN RIGHTS SITUATION IN THE TEMPORARILY OCCUPIED AUTONOMOUS REPUBLIC OF CRIMEA AND THE CITY OF SEVASTOPOL (UKRAINE). September 13, 2017 - June 30. 2018. Available online. In: https://digitallibrary.un.org/record/1643722. Consultation date: 28/03/2021.

SHULGA, Oleg. 2016. Detention by an authorized official in criminal proceedings: dissertation of the candidate of legal sciences National academy of internal affairs. Ukraine, Kyiv, 256 p.

TSVIKI, Vladislava. 2017. International legal protection of persons from enforced disappearances: dissertation of the candidate of legal sciences. Odessa. 247 p. 
YEROSHKIN, Mykola. 2019. "Prohibition of enforced disappearances in Ukraine" In: Countering cyber threats and human trafficking: materials of the international scientific-practical conference, Kharkiv pp. 71-72. Available online. In: http://dspace.univd.edu.ua/xmlui/bitstream/ handle/123456789/6140/Protydiia\%2okiberzahrozam\%2ota\%20 torhivli\%2oliudmy_konferentsiia_2019.pdf?sequence=1\&isAllowed $=\mathrm{y}$. Consultation date: 28/03/2021. 
Vol. 39 N $^{\circ} 69$

Esta revista fue editada en formato digital y publicada en julio de 2021, por el Fondo Editorial Serbiluz, Universidad del Zulia. Maracaibo-Venezuela 